\title{
Nocardia paucivorans sp. nov.
}

\author{
A. F. Yassin, ${ }^{1}$ F. A. Rainey, ${ }^{2}$ J. Burghardt, ${ }^{3}$ H. Brzezinka, ${ }^{4}$ M. Mauch ${ }^{5}$ \\ and K. P. Schaal ${ }^{1}$
}

Author for correspondence: A. F. Yassin. Tel: +49228 2874376. Fax: +492282874480. e-mail: yassin@mibi03.meb.uni-bonn.de

\footnotetext{
1 Institut für Medizinische Mikrobiologie und Immunologie der Universität Bonn, 53127 Bonn, Germany

2 Department of Biological Sciences, 508 Life Sciences Building, Louisiana State University, Baton Rouge, LA 70803, USA

3 DSMZ-Deutsche Sammlung von Mikroorganismen und Zellkulturen, D-38124 Braunschweig, Germany

4 Institut für Rechtsmedizin der Universität Bonn, 53111 Bonn, Germany

5 Institut für Mikrobiologie, Immunologie und Laboratoriumsmedizin, Krankenhaus Zehlendorf-Heckeshorn, 14109 Berlin, Germany
}

\section{Chemotaxonomic and 165 rDNA sequence analyses of an isolate from the sputa and bronchial secretions of a patient with chronic lung disease clearly demonstrated that it belongs to the genus Nocardia. DNA-DNA hybridization data, as well as the biochemical characteristics of the isolate, indicate that it belongs to a new species that differs from previously described members of the genus Nocardia. The name Nocardia paucivorans sp. nov. is proposed for this isolate and is represented by strain IMMIB D-1632 ${ }^{\top}$ (= DSM 44386 $)$.}

Keywords: Nocardia paucivorans, Nocardia brevicatena, chemotaxonomy, DNA-DNA hybridization, 16S rRNA gene sequence

\section{INTRODUCTION}

Members of the genus Nocardia form a complex group of organisms, of which Nocardia asteroides, Nocardia farcinica, Nocardia brasiliensis and Nocardia otitidiscaviarum are responsible for most cases of human nocardiosis. Nocardiae are morphologically characterized by the formation of extensively branched substrate hyphae which fragment into rod-shaped, non-motile elements. In addition, aerial hyphae are usually formed but are sometimes only visible microscopically (Gordon \& Mihm, 1957, 1962; Goodfellow $\&$ Lechevalier, 1989). Nocardiae are also characterized by the presence of a number of chemical markers including meso-diaminopimelic acid, arabinose and galactose in whole-cell hydrolysates (i.e. they possess cell wall chemotype IV sensu Lechevalier \& Lechevalier, 1970), mycolic acids with 40-60 carbon atoms, phospholipid type PII sensu Lechevalier et al. (1977) (i.e. phosphatidylethanolamine is the characteristic phospholipid), hexahydrogenated menaquinones with eight isoprene units as the major

The GenBank/EMBL/DDBJ accession number for the $16 \mathrm{~S}$ rDNA sequence of strain IMMIB D-1632 (= DSM 44386') is AF179865. quinones and a DNA G $+\mathrm{C}$ content of $64-72 \mathrm{~mol} \%$ (Goodfellow \& Lechevalier, 1989; Goodfellow, 1992).

Current methods of recognition of nocardiae in the clinical laboratory include the following: microscopic and colonial morphology; hydrolysis of casein, tyrosine, xanthine, hypoxanthine and testosterone; the degradation of urea and aesculin; acid production from carbohydrates; utilization of various carbon compounds as simultaneous sources of carbon and energy and various nitrogen-containing compounds as sources of carbon, energy and nitrogen; decarboxylation of citrate; and production of nitrate reductase (Mishra et al., 1980; Schaal, 1983). These tests differentiate species of medical importance such as $N$. asteroides, $N$. brasiliensis, $N$. farcinica, $N$. otitidiscaviarum, Nocardia brevicatena and Nocardia transvalensis as well as some additional mesophilic Nocardia species.

When subjected to chemotaxonomic methods used for the identification of clinical bacterial isolates the strain IMMIB D-1632 ${ }^{\mathrm{T}}$ was found to have chemotaxonomic characteristics which suggested its inclusion in the genus Nocardia. Further taxonomic and phylogenetic investigations indicated that it belongs to a new species that differs from previously described species of the 
genus Nocardia. In this paper, we describe the morphological, chemotaxonomic, physiological and phylogenetic characteristics of this new species.

\section{METHODS}

Bacterial strains. Strain IMMIB D- $1632^{\mathrm{T}}$ was isolated more than once from the sputa and bronchial secretions of a 51year-old patient with chronic lung disease. $N$. asteroides ATCC $19247^{\mathrm{T}}$ and Nocardia nova ATCC $33726^{\mathrm{T}}$ were obtained from the American Type Culture Collection (ATCC). N. brasiliensis DSM 43758 ${ }^{\mathrm{T}}, N$. farcinica DSM $43665^{\mathrm{T}}, N$. otitidiscaviarum DSM 43242 ${ }^{\mathrm{T}}, N$. brevicatena DSM 43024 ${ }^{\mathrm{T}}$, Nocardia carnea DSM $43397^{\mathrm{T}}$ and Nocardia vaccinii DSM $43285^{\mathrm{T}}$ were obtained from the German Culture Collection of Microorganisms and Cell Cultures (DSMZ).

Morphology and pigmentation. Strain IMMIB D-1632 ${ }^{\mathrm{T}}$ was grown on brain-heart infusion (BHI) agar and was examined for pigmentation, for the production of aerial hyphae and for other morphological characteristics. Cultures were grown for 4 weeks and observed weekly. Air-dried smears from BHI agar cultures were stained by the Gram and Ziehl-Neelsen methods in order to determine the Gram reaction and acid-fastness, respectively.

Physiological characteristics. The following properties were determined, for the above listed strains, as described previously: tests for the decomposition of adenine, guanine, hypoxanthine, xanthine, tyrosine, elastin, keratin and testosterone were performed using the method of Gordon (1967); aesculin decomposition was performed using the method of Gordon (1966); and casein- and gelatinhydrolysis tests were performed using the method of Gordon \& Mihm (1957). The urea-decomposition test was performed with urea agar base (catalogue no. CM 53; Oxoid) after the addition of $2 \cdot 2 \%$ urea. To determine the utilization of a substrate as a carbon source or as a simultaneous carbon and nitrogen source, we used the media described by Yassin et al. (1995).

Cell chemistry. The strains studied were cultivated at $37^{\circ} \mathrm{C}$ in shake flasks containing BHI (Difco) broth for 1 week. After being checked for purity at maximum growth, the organisms were killed with formaldehyde $(1 \%, v / v)$, harvested by centrifugation, washed with distilled water and freeze-dried. Analyses of whole-cell hydrolysates for amino acids and sugars were performed using the methods of Becker et al. (1964) and Lechevalier (1968), respectively. Mycolic acids were detected using acid methanolysis and one-dimensional TLC; Py-GC was performed as previously described by Yassin et al. (1993a); the composition of the mycolic acids was determined using electron-impact mass spectrometry according to Collins et al. (1982). Non-hydroxylated fatty acids were purified with preparative TLC and then separated, identified and quantified by GC as described by Yassin (1988). Menaquinones were extracted and purified by the method of Collins et al. (1977) and were identified by using a Finnigan Mat 212 mass spectrometer. Phospholipids were extracted, purified and identified as described previously (Yassin et al., 1993c).

DNA isolation and characterization. Cell mass for DNADNA hybridization was obtained as described above for cell chemistry determinations. DNA was isolated using the phenol method of Saito \& Miura (1963), with some modifications. The packed cells $(6.0 \mathrm{~g})$ were mixed with $20 \mathrm{mg}$ lysozyme dissolved in $6 \mathrm{ml}$ saline/EDTA $(\mathrm{pH} \mathrm{9.0)}$ and the mixture was kept at $37^{\circ} \mathrm{C}$ for $30 \mathrm{~min}$. When the cells were just beginning to lyse they were quickly frozen in an acetone/dry ice mixture and kept at $-20^{\circ} \mathrm{C}$ for $10 \mathrm{~min}$. Then $20 \mathrm{ml}$ Tris/SDS buffer ( $\mathrm{pH} 9.0$ ) was added to the frozen cells, which were suspended by stirring with a glass rod while being warmed in a water bath at $60^{\circ} \mathrm{C}$. When lysis was incomplete, the freezing and thawing processes were repeated. The cell suspension was then mixed with an equal volume of phenol saturated with Tris/SDS buffer $(\mathrm{pH} 9 \cdot 0)$ and the mixture was shaken by hand for $20 \mathrm{~min}$ at $4{ }^{\circ} \mathrm{C}$. The resulting emulsion was separated into two layers by centrifugation at 5000 r.p.m. for $15 \mathrm{~min}$. The nucleic acids were precipitated by gently mixing the supernatant with 2 vols cold ethanol. The thread-like precipitate was collected and dissolved in MOPS buffer and then purified by chromatography on hydroxyapatite using the method of Cashion et al. (1977). The $\mathrm{G}+\mathrm{C}$ content of DNA was determined by HPLC (Mesbah et al., 1989). DNA-DNA hybridization studies were carried out by using the thermal renaturation method (Yassin et al., 1993b).

16S rRNA gene sequence determination. Genomic DNA extraction, PCR-mediated amplification of the 16S rDNA and the purification of PCR products were carried out using procedures described previously (Rainey et al., 1996). Purified PCR products were sequenced using a Taq DyeDeoxy Terminator Cycle Sequencing kit (Applied Biosystems) according to the manufacturer's instructions. The Applied Biosystems 310 DNA Genetic Analyser was used for the electrophoresis of the sequence reaction products.

Phylogenetic analyses of 16S rRNA gene sequence data. The ae2 editor (Maidak et al., 1996) was used to align the $16 \mathrm{~S}$ rRNA gene sequence of strain IMMIB D-1632 ${ }^{\mathrm{T}}$ against the $16 \mathrm{~S}$ rRNA gene sequences of the validly described species of the genus Nocardia available from the public databases. The strain designations and nucleotide sequence accession numbers of the analysed sequences are as follows: $N$. asteroides ATCC $19247^{\mathrm{T}}$, X84850; N. brasiliensis DSM $43758^{\mathrm{T}}, \mathrm{X} 80608 ; N$. brevicatena ATCC $15333^{\mathrm{T}}, \mathrm{X} 80600 ; N$. carnea DSM 43397 ${ }^{\mathrm{T}}$, X80607; Nocardia crassostreae ATCC $700418^{\mathrm{T}}$, Z37989; N. farcinica ATCC 3318 ${ }^{\mathrm{T}}$, X80595; Nocardia flavorosea JCM 3332 ${ }^{\mathrm{T}}$, Z46754; N. nova ATCC $33726^{\mathrm{T}}$, X80593; N. otitidiscaviarum ATCC $14629^{\mathrm{T}}$, X80599; Nocardia pseudobrasiliensis ATCC 51512 ${ }^{\mathrm{T}}$, X84857; Nocardia salmonicida JCM 4826 ${ }^{\mathrm{T}}$, Z46750; Nocardia seriolae ATCC 43993 ${ }^{\mathrm{T}}$, X80592; N. transvalensis DSM 43405 ${ }^{\mathrm{T}}$, X80609; Nocardia uniformis JCM 3224 ${ }^{\mathrm{T}}$, Z46752; and $N$. vaccinii DSM 43285 ${ }^{\mathrm{T}}$, Z36927. The alignment used in the phylogenetic analyses comprised 1379 nucleotide positions between positions 38 and 1449 (Escherichia coli numbering; Brosius et al., 1978). The programs of the PHYLIP package including DNADIST and NEIGHBOR were used for the phylogenetic analyses (Felsenstein, 1993). The tree topology was reanalysed using 1000 bootstrapped data sets and the programs SEQBOOT, DNADIST and CONSENSE of the PHYLIP package (Felsenstein, 1993).

\section{RESULTS}

\section{Micromorphology}

The hyphae of strain IMMIB D-1632 ${ }^{\mathrm{T}}$ were Grampositive and slightly acid- and alcohol-fast. The vegetative hyphae were well developed with irregular 
Table 1. Physiological characteristics of strain IMMIB D-1632 ${ }^{\top}$ and some validly described Nocardia species

The following tests gave the same results (in parentheses) for all of the micro-organisms listed: hydrolysis of adenine $(-)$, gelatin $(-)$, guanine $(-)$, urea $(+)$ and keratin $(-)$; utilization of adipate $(-)$, benzoate $(-)$, lactate $(-)$, cellobiose $(-)$, lactose $(-)$, D-melezitose $(-)$, raffinose $(-)$, adonitol $(-)$, meso-erythritol $(-)$ and paraffin $(+)$ as sole sources of carbon and energy. w, Weakly utilized after incubation for 3 weeks.

\begin{tabular}{|c|c|c|c|c|c|c|c|c|c|}
\hline Characteristic & $\begin{array}{l}\text { IMMIB } \\
\text { D-1632 }\end{array}$ & $\begin{array}{l}\text { N. brevicatena } \\
{\text { DSM } 43024^{\mathrm{T}}}\end{array}$ & $\begin{array}{c}\text { N. carnea } \\
\text { DSM } 43397^{\mathrm{T}}\end{array}$ & $\begin{array}{c}\text { N. vaccinii } \\
\text { DSM 43285 }\end{array}$ & $\begin{array}{l}\text { N. asteroides } \\
\text { ATCC } 19247^{\mathrm{T}}\end{array}$ & $\begin{array}{c}\text { N. nova } \\
\text { ATCC 33726 }\end{array}$ & $\begin{array}{c}\text { N. brasiliensis } \\
\text { DSM 43758 }\end{array}$ & $\begin{array}{l}\text { N. farcinica } \\
\text { DSM } 43665^{\mathrm{T}}\end{array}$ & $\begin{array}{l}\text { N. otitidiscaviarum } \\
\text { DSM } \mathbf{4 3 2 4 2}^{\mathrm{T}}\end{array}$ \\
\hline \multicolumn{10}{|l|}{ Hydrolysis of: } \\
\hline Aesculin & - & + & + & - & + & - & + & + & + \\
\hline Casein & - & - & - & - & - & - & + & - & - \\
\hline Elastin & - & - & - & - & - & - & + & - & - \\
\hline Hypoxanthine & - & - & - & - & - & - & + & - & + \\
\hline Testosterone & - & - & - & - & + & - & - & + & + \\
\hline Tyrosine & - & - & - & - & - & - & + & - & - \\
\hline Xanthine & - & - & - & - & - & - & - & - & + \\
\hline \multicolumn{10}{|c|}{ Utilization as sole sources of carbon and energy: } \\
\hline Acetate & + & + & + & - & + & + & + & + & + \\
\hline Citrate & - & - & - & + & - & - & + & - & - \\
\hline Gluconate & - & - & - & + & + & - & - & - & $\mathrm{w}$ \\
\hline L-Arabinose & - & - & - & + & - & - & - & - & - \\
\hline Galactose & - & - & + & + & - & + & + & - & - \\
\hline Glucose & - & - & + & + & + & + & + & + & + \\
\hline Maltose & - & - & - & - & - & - & + & + & - \\
\hline L-Rhamnose & - & - & - & + & - & - & - & + & - \\
\hline Sucrose & - & - & - & - & + & - & $\mathrm{w}$ & + & - \\
\hline Trehalose & + & + & + & + & + & - & + & + & $\mathrm{w}$ \\
\hline Xylose & - & - & - & + & - & - & - & - & - \\
\hline myo-Inositol & - & - & - & - & - & - & + & - & + \\
\hline Mannitol & - & - & - & + & - & - & $\mathrm{w}$ & - & + \\
\hline D-Sorbitol & - & - & w & - & - & - & - & - & - \\
\hline Isoamyl alcohol & - & + & - & - & - & + & w & + & - \\
\hline 2,3-Butanediol & - & - & - & - & - & - & - & + & - \\
\hline 1,2-Propanediol & - & + & - & - & - & - & - & + & - \\
\hline$m$-Hydroxybenzoate & - & - & - & - & - & - & - & + & - \\
\hline$p$-Hydroxybenzoate & - & - & $\mathrm{w}$ & $\mathrm{w}$ & - & - & - & - & - \\
\hline \multicolumn{10}{|c|}{ Utilization as sole sources of carbon and nitrogen } \\
\hline Acetamide & - & - & - & - & - & - & - & + & - \\
\hline L-Alanine & - & - & - & - & - & - & + & - & + \\
\hline Gelatin & - & - & - & - & - & - & + & - & - \\
\hline Proline & - & - & - & - & + & - & + & - & - \\
\hline Serine & - & - & - & - & - & - & w & - & w \\
\hline
\end{tabular}

branches penetrating the agar and bearing white aerial hyphae. At a late stage of growth the hyphae fragment into rod-shaped elements.

\section{Physiological characteristics}

The physiological properties of strain IMMIB D$1632^{\mathrm{T}}$ and some of the validly described species of the genus Nocardia as determined in this study are shown in Table 1. Strain IMMIB D-1632 $2^{\mathrm{T}}$ hydrolysed urea but not adenine, aesculin, casein, elastin, gelatin, guanine, hypoxanthine, keratin, testosterone, tyrosine or xanthine. It utilized acetate, trehalose and paraffin as carbon sources but did not utilize adipate, benzoate, citrate, gluconate, lactate, arabinose, cellobiose, galactose, glucose, lactose, maltose, melezitose, raffinose, rhamnose, sucrose, xylose, adonitol, meso-erythritol, myo-inositol, mannitol, sorbitol, isoamyl alcohol, 2,3butanediol, 1,2-propanediol, $m$-hydroxybenzoate or $p$ hydroxybenzoate. Strain IMMIB D-1632 ${ }^{\mathrm{T}}$ did not utilize acetamide, alanine, gelatin, proline or serine as simultaneous carbon and nitrogen sources.

\section{Lipid analysis}

One-dimensional TLC of whole-cell acid methanolysates of strain IMMIB D- $1632^{\mathrm{T}}$ revealed the presence of two lipid spots on the chromatogram. The lower one corresponds to mycolic acids, as identified by its $R_{F}$ value $(0 \cdot 47)$ and the higher spot corresponds to the non-hydroxylated fatty acids.

Py-GC of the pure mycolic acid methyl esters (isolated by preparative TLC) from strain IMMIB D-1632 released fatty acid methyl esters of C14:0 (17.47\%) and $\mathrm{C} 16: 0(82.53 \%)$ as pyrolysis cleavage products. Mass spectral analysis of the pure mycolate revealed the presence of mycolic acids with 48-54 carbon atoms with 2-4 double bonds. Gas chromatographic analyses of the non-hydroxylated fatty acid methyl esters revealed the presence of hexadecenoate $(33.4 \%$ of total fatty acids), hexadecanoate $(2 \cdot 3 \%)$, octadecenoate $(5.8 \%)$, octadecanoate $(2.9 \%)$ and tuberculostearic acid (10-methyl octadecanoate, $32.5 \%$ ) as the major cellular fatty acid methyl esters.

Polar lipid analysis showed that strain IMMIB D- 


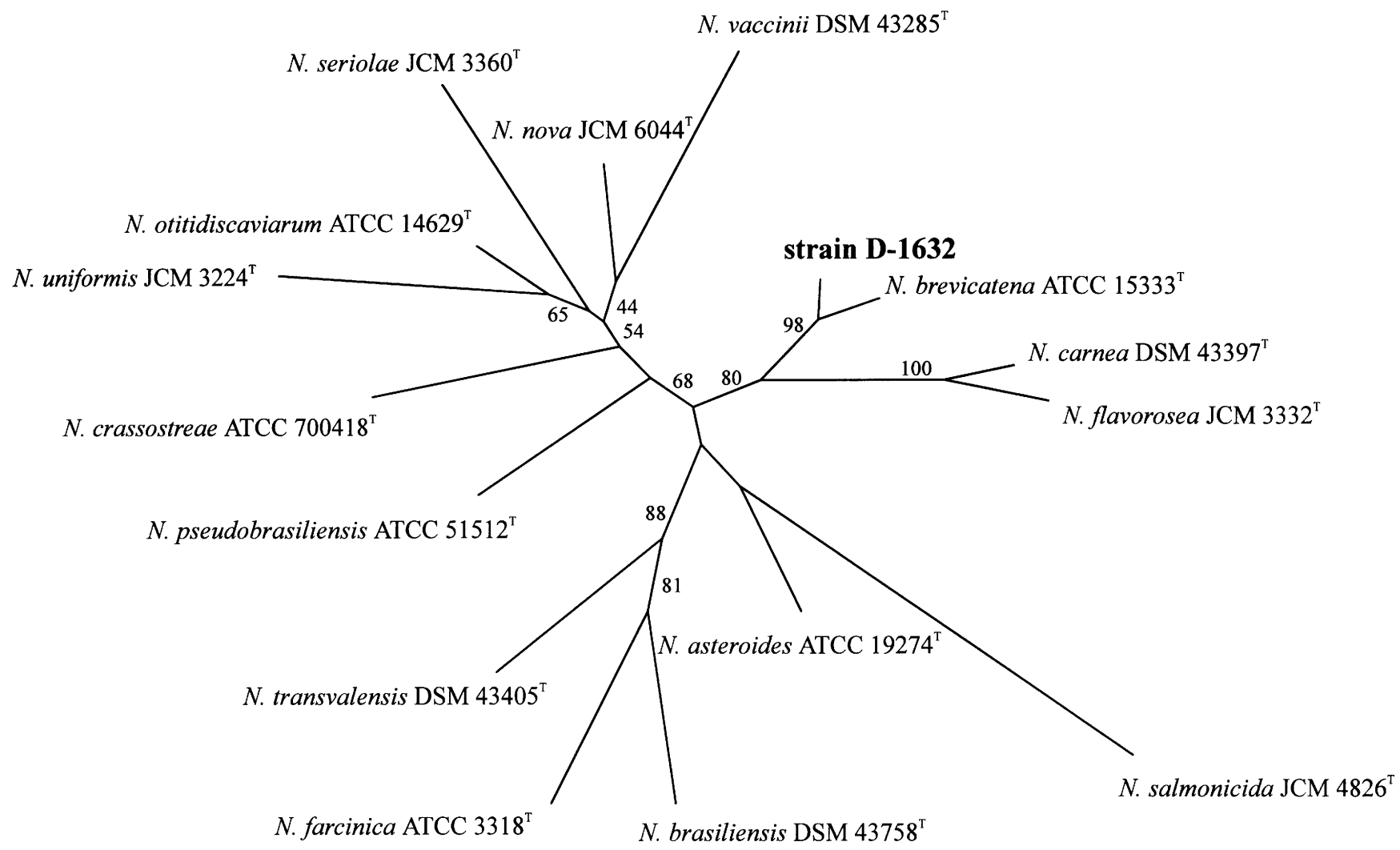

Fig. 1. Unrooted phylogenetic tree showing the position of strain IMMIB D-1632 ${ }^{\top}$ (=DSM $44386^{\top}$ ) within the radiation of species of the genus Nocardia. Bootstrap values, expressed as a percentage of 1000 replications, are shown at the branching points. Bar, 2 inferred nucleotide substititions per 100 nucleotides.

$1632^{\mathrm{T}}$ contains phosphatidylethanolamine, phosphatidylinositol, phosphatidylinositol mannoside and diphosphatidylglycerol as the characteristic phospholipids.

The composition of the respiratory quinones of strains IMMIB D-1632 ${ }^{\mathrm{T}}$ was examined. On reverse-phase TLC using RP-18, the lipid extract from this strain gave two separate bands. Mass spectral analysis of the main component showed, in the high-mass region, a strong peak at $m / z 720$ attributable to $M^{+}$as well as peaks of considerable intensity at $\mathrm{m} / z$ values of 582 and 594. These correspond to a hexahydrogenated menaquinone with eight isoprene units in which the two terminal isoprene moieties are cyclized (Howarth et al., 1986). The second band shows, in the high-mass region, a strong peak at $m / z 736$ attributable to $M^{+}$, with a second intense peak at $m / z 720$ (corresponding to loss of oxygen from $\mathrm{M}^{+}$), while in the low-mass region it shows a peak of medium intensity at $\mathrm{m} / z 241$ (indicative of an additional oxygen in the naphtho- quinone ring system). This mass spectrum of the second band corresponds to a hexahydrogenated epoxymenaquinone with eight isoprene units in which the last two isoprene moieties are cyclized (Collins et al., 1987).

\section{Phylogenetic analysis}

The almost complete 16S rRNA gene sequence of strain IMMIB D-1632 ${ }^{\mathrm{T}}$ comprising 1459 nucleotides ( $>95 \%$ of the E. coli sequence; Brosius et al., 1978) was determined in this study. The unrooted phylogenetic tree (shown in Fig. 1) was constructed from evolutionary distances by the neighbour-joining method. A total of 1379 nucleotides present in all strains between positions 38 and 1449 (E. coli positions) was used for these analyses and compared with the sequences of the type strains of the 15 validly described Nocardia species. The phylogenetic tree, based on the 16S rRNA gene sequence, shown in Fig. 1 indicates the position of strain IMMIB D-1632 
within the radiation of species of the genus Nocardia. The 16S rDNA sequence of strain IMMIB D-1632 contains all of the 16S rDNA signature nucleotides defined for the family Nocardiaceae (Stackebrandt et al., 1997). The 16S rRNA gene sequence similarity values between strain IMMIB D-1632 ${ }^{\mathrm{T}}$ and the other Nocardia species included in the tree (Fig. 1) show strain IMMIB D-1632 ${ }^{\mathrm{T}}$ to be closely related at the $16 \mathrm{~S}$ rRNA gene sequence level to Nocardia brevicatena $(99.6 \%)$. The $16 \mathrm{~S}$ rRNA gene sequence similarity values for the sequence of strain IMMIB D-1632 relative to other Nocardia species are in the range $97 \cdot 0-98 \cdot 3 \%$ (data not shown). These values and the results shown in the phylogenetic tree (Fig. 1) indicate that strain IMMIB D-1632 ${ }^{\mathrm{T}}$ is a member of the genus Nocardia and shows a high degree of relatedness to $N$. brevicatena.

\section{DNA characteristics}

The results of triplicate determinations of the $\mathrm{G}+\mathrm{C}$ content of the DNA of strain IMMIB D-1632 ${ }^{\mathrm{T}}$ was $65.9 \mathrm{~mol} \%$. The levels of relatedness (binding rates) of triplicate measurements between DNAs of this strain and the DNA of $N$. brevicatena DSM $43024^{\mathrm{T}}$ is $61.9 \%$.

\section{DISCUSSION}

The 16S rDNA sequence comparison clearly shows that strain IMMIB D- $1632^{\mathrm{T}}$ is a member of the family Nocardiaceae (Stackebrandt et al., 1997), since the determined sequence contains all of the signature nucleotides designated for this lineage. The high values for $16 \mathrm{~S}$ rRNA gene sequence similarity to other previously described members of the genus Nocardia $(97 \cdot 0-99 \cdot 6 \%)$ support the addition of strain IMMIB $\mathrm{D}-1632^{\mathrm{T}}$ to this genus.

The intergeneric relationships of the Nocardia species (Fig. 1) based on 16S rRNA gene sequence comparison shows strain IMMIB D-1632 $2^{\mathrm{T}}$ to cluster with $N$. brevicatena. Even though the 16S rRNA gene sequences of these two taxa share $99.6 \%$ sequence similarity, the results of DNA-DNA homology studies $(61.9 \%$, which is clearly lower than the cut-off point of species as specified by Wayne et al., 1987) and phenotypic testing show them to represent distinct species. A comparable case was found for $N$. flavorosea and N. carnea (Chun et al., 1998).

The phenotypic characteristics of strain IMMIB $\mathrm{D}-1632^{\mathrm{T}}$ were compared with those of validly described Nocardia species. Chemotaxonomically, strain IMMIB D-1632 ${ }^{\mathrm{T}}$ shows the characteristics of members of the genus Nocardia. All of them contain galactose and arabinose as characteristic whole-cell sugars in addition to meso-diaminopimelic acid as the wall diamino acid (i.e. they are wall chemotype IV organisms); all contain nocardomycolic acid which, upon pyrolysis, releases fatty acids that range from C14:0 to C18:0 carbon atoms as cleavage products; and their fatty acid profiles consist of saturated, unsaturated and 10-methyl-branched-chain fatty acids. All of them contain hexahydrogenated menaquinones $\mathrm{MK}-8\left(\mathrm{H}_{6}\right)$, in which the two terminal isoprene moieties are cyclized, as the major isoprenoid quinones and all of them possess phospholipid type PII with phosphatidylethanolamine as the characteristic phospholipid. These chemotaxonomic similarities are supported by the high levels of $16 \mathrm{~S}$ rRNA gene sequence similarity (97-99.6\%) observed between isolate IMMIB D-1632 $2^{\mathrm{T}}$ and members of the genus Nocardia.

In contrast to the chemotaxonomic similarities of strain IMMIB D-1632 ${ }^{\mathrm{T}}$ and other members of the genus Nocardia, the results of our physiological tests (Table 1) revealed clear differences between them. Isolate IMMIB D-1632 ${ }^{\mathrm{T}}$ can be differentiated from $N$. brevicatena DSM $43024^{\mathrm{T}}$ by its inability to hydrolyse aesculin as well as its inability to utilize isoamyl alcohol and 1,2-propanediol as sources of carbon and energy. Strain IMMIB D- $1632^{\mathrm{T}}$ cannot be differentiated from $N$. vaccinii DSM $43285^{\mathrm{T}}$ and $N$. nova ATCC $33726^{\mathrm{T}}$ on the basis of substrate-hydrolysis tests; all three strains are only able to hydrolyse urea and are unable to hydrolyse adenine, casein, elastin, gelatin, guanine, hypoxanthine, keratin, testosterone, tyrosine and xanthine. However, strain IMMIB D-1632 ${ }^{\mathrm{T}}$ can be differentiated from $N$. vaccinii DSM $43285^{\mathrm{T}}$ and Nocardia nova ATCC $33726^{\mathrm{T}}$ on the basis of carbonassimilation tests (Table 1). Furthermore, strain IMMIB D-1632 ${ }^{\mathrm{T}}$ cannot be differentiated from $N$. carnea DSM $43397^{\mathrm{T}}$ and $N$. nova ATCC $33726^{\mathrm{T}}$ on the basis of utilization of a substrate as a simultaneous carbon and nitrogen source; all three species are unable to utilize acetamide, alanine, gelatin, proline or serine as simultaneous carbon and nitrogen sources. Strain IMMIB D-1632 ${ }^{\mathrm{T}}$, however, can be differentiated from $N$. carnea DSM $43397^{\mathrm{T}}$ on the basis of tests of substrate hydrolysis as well as a test of carbon source assimilation. Strain IMMIB D-1632 ${ }^{\mathrm{T}}$ can be differentiated from $N$. asteroides ATCC $19247^{\mathrm{T}}, N$. brasiliensis DSM $43758^{\mathrm{T}}, N$. farcinica DSM $43665^{\mathrm{T}}$ and $N$. otitidiscaviarum DSM $43242^{\mathrm{T}}$ by tests of substrate hydrolysis, carbon assimilation and/or utilization of a substrate as a simultaneous source of carbon and nitrogen (Table 1).

We therefore propose that strain IMMIB D-1632 should be described as a new species of the genus Nocardia. It represents the type species of this new species and has been deposited in the German Collection of Microorganisms and Cell Cultures as strain DSM $44386^{\mathrm{T}}$. The type strain was isolated more than once from the sputa and broncho-alveolar secretions of a 51-year-old man suffering from a lung disease. The description of this species is given below.

\section{Nocardia paucivorans sp. nov.}

Nocardia paucivorans (pau.ci.vo'rans. L. adj. paucus little; L. v. vorare to eat, to devour; L. pres. part. vorans eating; M.L. adj. paucivorans eating little, 
referring to the few compounds that are utilized as sole sources of carbon and energy).

The hyphae are Gram-positive and slightly acid- and alcohol-fast. The vegetative hyphae are well developed with irregular branches penetrating the agar and bear white aerial hyphae. At a late stage of growth the hyphae fragment into rod-shaped elements. The organism contains meso-diaminopimelic acid as the wall diamino acid in addition to galactose and arabinose in whole-cell hydrolysates (i.e. the cell wall chemotype is chemotype IV). It has mycolic acids with 48-54 carbon atoms and 2-4 double bonds $\left(\mathrm{C}_{48: 3}, \mathrm{C}_{50: 4}, \mathrm{C}_{52: 2}, \mathrm{C}_{52: 4}\right.$, $\mathrm{C}_{54: 2}$ and $\mathrm{C}_{54: 3}$ ) that are cleaved upon pyrolysis to release fatty acids with $\mathrm{C}_{14: 0}$ and $\mathrm{C}_{16: 0}$ carbon atoms, with $\mathrm{C}_{16: 0}$ as the major cleavage product; this $N$. paucivorans has a cellular fatty acid profile that comprises saturated, unsaturated and 10-methylbranched fatty acids. It possesses type PII phospholipids with significant amounts of phosphatidylethanolamine. The menaquinone system consists of partially saturated menaquinones with eight isoprene units in which the two terminal isoprene moieties are cyclized; $\mathrm{MK}-8\left(\mathrm{H}_{6}\right)$ is the major menaquinone and minor amounts of 2,3-epoxy-MK- $8\left(\mathrm{H}_{6}\right)$ are also present. It hydrolyses urea but not adenine, aesculin, casein, elastin, gelatin, guanine, hypoxanthine, keratin, testosterone, tyrosine or xanthine. It assimilates acetate, trehalose and paraffin as carbon sources but does not assimilate adipate, benzoate, citrate, gluconate, lactate, arabinose, cellobiose, galactose, glucose, lactose, maltose, melezitose, raffinose, rhamnose, sucrose, xylose, adonitol, meso-erythritol, myoinositol, mannitol, sorbitol, isoamyl alcohol, 2,3butanediol, 1,2-propanediol, $m$-hydroxybenzoate or $p$-hydroxybenzoate. It does not utilize acetamide, alanine, gelatin, proline or serine as simultaneous carbon and nitrogen sources. The $\mathrm{G}+\mathrm{C}$ content of the DNA is $65.9 \mathrm{~mol} \%$. The type strain of Nocardia paucivorans is strain IMMIB D-1632 $\left(=\right.$ DSM $\left.44386^{\mathrm{T}}\right)$.

\section{REFERENCES}

Becker, B., Lechevalier, M. P., Gordon, R. E. \& Lechevalier, H. A. (1964). Rapid differentiation between Nocardia and Streptomyces by paper chromatography of whole cell hydrolysates. Appl Microbiol 12, 421-423.

Brosius, J., Palmer, M. L., Kennedy, P. J. \& Noller, H. F. (1978). Complete nucleotide sequence of the 16S ribosomal RNA gene from Escherichia coli. Proc Natl Acad Sci USA 75, 4801-4805.

Cashion, P., Holder-Franklin, M. A., McCully, J. \& Franklin, M. (1977). A rapid method for the base ratio determination of bacterial DNA. Anal Biochem 81, 461-466.

Chun, J., Seong, C.-N., Bae, K. S., Lee, K.-J., Kang, S.-O., Goodfellow, M. \& Hah, Y. C. (1998). Nocardia flavorosea sp. nov. Int J Syst Bacteriol 48, 901-905.

Collins, M. D., Pirouz, T., Goodfellow, M. \& Minnikin, D. E. (1977). Distribution of menaquinones in actinomycetes and corynebacteria. J Gen Microbiol 100, 221-230.

Collins, M. D., Goodfellow, M. \& Minnikin, D. E. (1982). A survey of the structures of mycolic acid in Corynebacterium and related taxa. J Gen Microbiol 128, 129-149.
Collins, M. D., Howarth, O. W., Grund, E. \& Kroppenstedt, R. M. (1987). Isolation and structural determination of new members of the vitamin $\mathrm{K}_{2}$ series in Nocardia brasiliensis. FEMS Microbiol Lett 41, 35-39.

Felsenstein, J. (1993). PHYLIP (Phylogenetic Inference Package) version 3.5.1. Seattle: Department of Genetics, University of Washington.

Goodfellow, M. (1992). The family Nocardiaceae. In The Prokaryotes, 2nd edn, pp. 1188-1213. Edited by A. Balows, H. G. Trüper, M. Dworkin, W. Harder \& K. H. Schleifer. New York: Springer.

Goodfellow, M. \& Lechevalier, M. P. (1989). Genus Nocardia. Trevisan 1889, 9 $9^{\mathrm{AL}}$. In Bergey's Manual of Systematic Bacteriology, vol. 2, pp. 1458-1471. Edited by S. T. Williams, M. E. Sharpe \& J. G. Holt. Baltimore: Williams \& Wilkins.

Gordon, R. E. (1966). Some criteria for the recognition of Nocardia madurae (Vincent) Blanchard. J Gen Microbiol 45, 355-364.

Gordon, R. E. (1967). The taxonomy of soil bacteria. In The Ecology of Soil Bacteria, pp. 293-321. Edited by T. R. G. Gray \& B. Parkinson. Liverpool: University Press.

Gordon, R. E. \& Mihm, J. M. (1957). A comparative study of some strains received as nocardiae. J Bacteriol 73, 15-27.

Gordon, R. E. \& Mihm, J. M. (1962). The type species of the genus Nocardia. J Gen Microbiol 27, 1-10.

Howarth, O. W., Grund, E., Kroppenstedt, R. M. \& Collins, M. D. (1986). Structural determination of a new naturally occurring cyclic vitamin K. Biochem Biophys Res Commun 140, 916-923.

Lechevalier, M. P. (1968). Identification of aerobic actinomycetes of clinical importance. J Lab Clin Med 71, 934-944.

Lechevalier, M. P. \& Lechevalier, H. A. (1970). A critical evaluation of the genera of aerobic actinomycetes. In The Actinomycetales, pp. 393-405. Edited by H. Prauser. Jena: Gustav Fischer.

Lechevalier, M. P., de Bievre, C. \& Lechevalier, H. A. (1977). Chemotaxonomy of aerobic actinomycetes: phospholipid composition. Biochem Syst Ecol 5, 249-260.

Maidak, B. I., Olsen, G. J., Larsen, N., Overbeek, R., McCaughey, M. J. \& Woese, C. R. (1996). The Ribosomal Database Project (RDP). Nucleic Acids Res 24, 82-85.

Mesbah, M., Premachandran, U. \& Whitman, W. B. (1989). Precise measurement of the $\mathrm{G}+\mathrm{C}$ content of deoxyribonucleic acid by high-performance liquid chromatography. Int $J$ Syst Bacteriol 39, 159-167.

Mishra, S. K., Gordon, R. E. \& Barnett, D. A. (1980). Identification of nocardiae and streptomycetes of medical importance. J Clin Microbiol 11, 728-736.

Rainey, F. A., Ward-Rainey, N., Kroppenstedt, R. M. \& Stackebrandt, E. (1996). The genus Nocardiopsis represents a phylogenetically coherent taxon and a distinct actinomycete lineage: proposal of Nocardiopsiaceae fam. nov. Int J Syst Bacteriol 46, 1088-1092.

Saito, H. \& Miura, K.-I. (1963). Preparation of transforming deoxyribonucleic acid by phenol treatment. Biochim Biophys Acta 72, 619-629.

Schaal, K. P. (1983). Laboratory diagnosis of actinomycete diseases. In The Biology of the Actinomycetes, pp. 425-456. Edited by M. Goodfellow, M. Mordarski \& S. T. Williams. London \& New York: Academic Press.

Stackebrandt, E., Rainey, F. A. \& Ward-Rainey, N. L. (1997). 
Proposal for a new hierarchic classification system, Actinobacteria classis nov. Int J Syst Bacteriol 47, 479-491.

Wayne, L. G., Brenner, D. J., Colwell, R. R. \& 9 other authors (1987). Report of the Ad Hoc Committee on recognition of approaches to bacterial systematics. Int J Syst Bacteriol 37, 463-464.

Yassin, A. F. (1988). Chemotaxonomic Untersuchungen zur vereinfachten Differenzierung und Identifizierung von aeroben Aktinomyzeten und Mykobakterien. Innaugural-Dissertation zur erlangung des Doktorgrades der Mathematische, Naturwissenschaftlichen Fakultät der Rheinischen Friedrich-Wilhelms-Universität Bonn.

Yassin, A. F., Binder, C. \& Schaal, K. P. (1993a). Identification of mycobacterial isolates by thin-layer and capillary gas-liquid chromatography under diagnostic routine conditions. Zentbl Bakteriol 278, 34-48.

Yassin, A. F., Galinski, E. A., Wohlfarth, A., Jahnke, K.-D., Schaal, K. P. \& Trüper, H. G. (1993b). A new actinomycete species, Nocardiopsis lucentensis sp. nov. Int $J$ Syst Bacteriol 43, 266-271.

Yassin, A. F., Haggenei, B., Budzikiewicz, H. \& Schaal, K. P. (1993c). Fatty acid and polar lipid composition of the genus Amycolatopsis: application of fast atom bombardment mass spectrometry to structure analysis of underivatized phospholipids. Int J Syst Bacteriol 43, 414-420.

Yassin, A. F., Rainey, F. A., Brzezinka, H., Burghardt, J., Lee, H. L. \& Schaal, K. P. (1995). Tsukamurella inchonensis sp. nov. Int $J$ Syst Bacteriol 45, 522-527. 